\title{
Roles and Groups Dynamic as a Systematic Approach to Improve Collaborative Learning in Classroom
}

\author{
Ana Serrano Tierz, Anna Maria Biedermann* \\ Department of Design and Manufacturing Engineering, University of Zaragoza, Zaragoza, Spain \\ Email:anatierz@unizar.es,anna@unizar.es
}

Received 29 September 2015; accepted 20 November 2015; published 23 November 2015

Copyright (C) 2015 by authors and Scientific Research Publishing Inc.

This work is licensed under the Creative Commons Attribution International License (CC BY).

http://creativecommons.org/licenses/by/4.0/

(c) (i) Open Access

\begin{abstract}
University degrees currently have aspects in their curriculum such as the need to develop the students' abilities regarding teamwork, interpersonal skills and problems solving. For this reason, when making educational programming, the use of methodologies that include activities that encourage active student participation, can be of a great help. The proposal of Groups and Roles that is showed is based on the principles of active methodologies, in which the student takes an active role in their learning process, promoting a model that encourages him/her to reflect, analyze, draw conclusions, etc., seeking his/her involvement and commitment to make this process more formative. This work shows the results obtained after the application of this methodology in the lectures of the subjects from 1st, 2nd and 3rd Degree in Industrial Design and Product Development Engineering at the University of Zaragoza. With the development of these activities, the following aims have been achieved: detecting the mayor learning difficulties for the students; implementing the link between the contribution of contents of the subject, under study, and the further professional development of the students; developing students' creativity; encouraging the awareness towards quality within work; developing skills in interpersonal relations and increasing motivation at work. This dynamics even though it has required an important degree of involvement, both by students and teachers, has been a positive and enriching experience.
\end{abstract}

\section{Keywords}

Active Learning, Roles, Collaborative Learning, Classroom Management, Systematic Approach

\footnotetext{
*A research group member at Observtorio Aragonés de Arte en la Esfera Pública Financed by Gobierno de Aragón with FEDER Funds.
} 


\section{Introduction}

Since the establishment of the Bologna Plan in European universities as a referential frame, the proposed methodological approaches have provided an identity marker that focuses mainly on students, their autonomy, their processes of acquisition and construction of knowledge and on them playing active role in their learning (Huber, 2008). This model based on constructivist teaching strategies has mobilised an important change as it proposes modifying the conceptions and teaching styles of university professors, with respect to teaching based on traditional education strategies (Caballero \& Botía, 2015). Thus, the university system is facing the challenge of proposing a transformation in terms of the teaching-based education model, fostering a new learning-based model, which commits to the profile of an active student who can ask questions, investigate, select and organise information, analyse data, draw conclusions, express themselves adequately, etc. (Rekalde, Martínez, \& Marko, 2012). The methodology based on active learning model can be understood as the generation of knowledge through experimentation (Barros \& Ramízez, 2009). For authors Araujo \& Slomski (2013), "the education of future professionals requires skills development, critical-thinking and reflesive ploblem-solving ability”.

Konopka (2015) proposes active learning as a technique that complements the traditional reading by its interactive nature and that teachers apply with the intention of maintaining student interest and creativity.

Fernández (2006) states that teaching methods with the participation of students, where the responsibility for learning depends on their activity, engagement and commitment, are more formative than informative, as they generate a more in-depth, significant and long-lasting learning, facilitating the transfer to more heterogeneous contexts. In this regard, it is important to have an in-depth knowledge of the methodological repertoire and experiment with it to evaluate the possibilities offered by the different strategies in order to adapt them to our needs, with the aim of achieving a learning context that fosters the students' engagement. The possibility of developing academic and professional competences, developing interpersonal and communication skills, and even changing attitudes are attributed to these methodologies. For Ruiz (2011) active methodologies promote the development of the basic competences of teacher training, and make it possible to dynamically combine attributes related to knowledge, skills, attitudes and responsibilities, thus showing the learning results of a programme, which the students are able to demonstrate at the end of the learning process. Palazón, Gómez, Gómez, Pérez, \& Gómez (2011) point out that this type of methodology has a significant influence on the learning quality of these students and on their academic results. However, it must be taken into account that the important part of the methodology used is its adaptation to the learnings and to the intended purpose, considering the competences to be developed, if they used in a technically correct manner and if they are not used as a reaction to each other (Rodríguez, 2011). Professor López (2005) indicates in his book Metodología participativa en la enseñanza universitaria (Participative methodology in university teaching) that to make the move towards participatory methodology, professors must be trained, not only in positive attitudes and values, but also in new teaching skills that will enable them to help their students change at a cognitive, emotional and attitudinal level. Likewise, the aspects of innovation and renovation are also essential, entailing changes in methodology, ideas, values and beliefs both in professors and students. In any case, as indicated by Zabalza (2003), the methodological decision teeters on a tightrope, as there are variables that can be changed, but others are sometimes impossible to change.

From the viewpoint of the teachers' motivation in applying this type of methodology, Lobato \& Madinabeitia, (2011) point out that teachers, who are undergoing a learning process in active methodologies through the Eragin programme carried out at the University of the Basque Country, are intrinsically very motivated, and despite the fact that extrinsic motivations are present in this learning process, they are relegated to a second plane. This conclusion coincides with that obtained by Bruinsma \& Jansen (2010) who point out that teaching enthusiasm is positively related to the quality of the training programme and satisfactory teaching experiences in the classroom.

After more than one decade of experiences in incorporating learning strategies based on active methodologies applied to the field of university education, it is a good moment to reflect upon the possibilities offered by these methodologies. A review of the most commonly used active methodologies is shown (Table 1).

Given that the majority of the competences to be developed by engineering students have a high practical component and the future exercise of the profession entails situations where they will have to carry out an active role, this type of methodology is adequate in their university education, especially in those subjects where the students express certain doubts about the utility of these subjects in their future professional lives, such as for example, Technical Drawing (Vergara \& Rubio, 2013). These methods permit associating theoretical explanations with direct application in professional situations and real-life (Benegas \& Villegas, 2006). Thus, students 
Table 1. Models of most used active methodologies.

\begin{tabular}{|c|c|c|}
\hline & Method & Application \\
\hline Proyect based learning & $\begin{array}{l}\text { In PBL, the development of learning is reached } \\
\text { through an experience that consists in carrying out a } \\
\text { project. This must be perceived by the students as } \\
\text { something attractive and feasible and it is carried out } \\
\text { in working groups. }\end{array}$ & $\begin{array}{l}\text { Bonwell \& Eison (1991) } \\
\text { Markham (2003) } \\
\text { Konrad (2004) } \\
\text { Moreira, Mesquita, \& Hattum-Janssen (2011) } \\
\text { Van Hattum, Fischer, \& Moreira (2011) } \\
\text { Garrigós \& Valero (2012) } \\
\text { Francischetti et al. (2014) }\end{array}$ \\
\hline Learning contract & $\begin{array}{l}\text { This is an agreement based on communication and on } \\
\text { trust that defines the commitments assumed by the } \\
\text { professor and the student to ensure the quality of the } \\
\text { training and achievement of the subject goals. To this } \\
\text { end, the students form groups and design the } \\
\text { exercises, learning strategies, self-assessment and the } \\
\text { practical sessions. }\end{array}$ & $\begin{array}{l}\text { Przesmycki (2000) } \\
\text { Franquet, Marín, Marqués, \& Rivas (2006) } \\
\text { Sugrañes (2006) } \\
\text { Martínez (2008) }\end{array}$ \\
\hline Problem based learning & $\begin{array}{l}\text { The starting point of problem based learning is a } \\
\text { problem or situation and the objective is to identify } \\
\text { learning needs. }\end{array}$ & $\begin{array}{l}\text { Johnstone \& Biggs (1998) } \\
\text { Milne \& Connell (2001) } \\
\text { Kanet \& Barut (2003) } \\
\text { Hansen (2006) } \\
\text { Atienza (2008) } \\
\text { Saiz \& Fernández (2012) }\end{array}$ \\
\hline Case study & $\begin{array}{l}\text { The use of authentic cases creates group work } \\
\text { dynamics and contributes to a good interaction with } \\
\text { the professor. This activity encourages students as } \\
\text { they see the real application of the knowledge } \\
\text { acquired. }\end{array}$ & $\begin{array}{l}\text { Martínez (2006) } \\
\text { Maldonado (2006) } \\
\text { Ramos, Herrera, \& Ramírez (2010) } \\
\text { Villarreal \& Landeta (2010) }\end{array}$ \\
\hline Simulation & $\begin{array}{l}\text { This activity is based on a real life situation, which is } \\
\text { open-ended and where no responses to the problems or } \\
\text { situations that may arise are more correct than others. }\end{array}$ & $\begin{array}{l}\text { Jones (1995) } \\
\text { Andreu, García, \& Mollar (2005) } \\
\text { Ruiz, Magallón, \& Muñoz (2006) } \\
\text { Juguera, Díaz, Pérez, Leal, Rojo, \& Echevarría } \\
\text { (2014) }\end{array}$ \\
\hline Portfolio & $\begin{array}{l}\text { This is a method that fosters the construction of own } \\
\text { knowledge through the compilation of significant } \\
\text { material that represents a basis for the assessment. }\end{array}$ & $\begin{array}{l}\text { Corominas (2000) } \\
\text { Barberá (2005) } \\
\text { Barragán (2005) } \\
\text { Hernández, González, \& Guerra (2006) } \\
\text { Prendes \& Sánchez (2008) } \\
\text { Romero \& Crisol (2011) } \\
\text { Pomares (2011) }\end{array}$ \\
\hline Module work & $\begin{array}{l}\text { Module work proposes carrying out a collaborative } \\
\text { and interdisciplinary work that integrates different } \\
\text { subjects, facilitating the development of transversal } \\
\text { and specific skills of the qualification. }\end{array}$ & $\begin{array}{l}\text { Rekalde, Martínez, \& Marko (2012) } \\
\text { Serrano, Hernández, Pérez, \& Biel (2013) }\end{array}$ \\
\hline
\end{tabular}

can see for themselves the relationship between certain theoretical aspects and their utility.

The methodology of module projects (Manchado \& López, 2012; Serrano, Hernández, Pérez, \& Biel, 2013) has been applied since the implementation of the Engineering Degree in Industrial Design and Product Development (GIDIDP) of the University of Zaragoza. Here, students play an active role, associating the knowledge they acquire about the different subjects. The groups and roles systematic approach, presented in this paper, aims to complement the methodological process applied in the GIDIDP, in which an active role of the student is propitiated, increasing the motivation and collaborative learning in acquiring theoretical contents.

This work has been accepted as an Innovation Teaching Projects 2014-2015 at the University of Zaragoza. This experience has involved freshmen (participating in the subject of Artistic Expression) during the first semester. After this pilot experience and obtaining the necessary feedback from students the methodology has been implemented with some changes and improvements in the 2nd semester with sophomores (in the subject of Graphic Design and Communication) and juniors (subject of Corporate Identity).

The goal of this paper is to show the results obtained after the application of this methodology in the lectures of the subjects from 1st, 2nd and 3rd Degree in Industrial Design and Product Development Engineering at the University of Zaragoza, with the aim of presenting its efficacy, flexibility and transferability to other educational contexts and encouraging lecturers to implement it in their teaching practice. The significance of this paper con- 
sists in the presentation of a new active methodology developed by the authors and its viability in the context of other active systematic approaches.

This paper structure is as follows: Section 2 contains the principles of the systematic approach conducted in the experience of working with groups and roles. In Section 2.1, there is presented an example of this methodology carried out in one of the three subjects in which this activity has implemented and paragraph 2.2 presents comparative of methodological application between this three subjects. Section 3 contains the results with the discussion of the work and finally section 4 presents the conclusions of the investigation.

\section{Methodological Proposal}

The systematic approach by groups and roles is based on a learning of theoretical contents in which the student takes an active role.

The aim of implementing this methodology is to:

- Associate the contributions of the subject to the field of knowledge.

- Foster the active participation of students in the teaching/learning process.

- Get to know the students' learning difficulties and their improvement proposals.

- Increase the students' engagement and responsibility in their learning process and interest in the contents.

The experience has enabled students to perform different activities worked collaboratively. These activities have been put forward throughout the semester and students have been able to develop systemic, instrumental, interpersonal specific competencies assigned to different roles.

The following tasks have been assigned to each one of the roles (Figure 1):

- Red group: its mission was to detect the difficulties in learning the topic or carrying out the exercises proposed, indicating which concepts required explanation and why they represented a difficulty. In this regard, solutions were invited to help towards understanding. The aim of the activities of this group was for the student to develop instrumental competences.

- Green group: its mission was to identify the practical meaning of the content dealt with in the subject and detect contributions to the discipline of product design. The aim of the activities of this group was for students to develop specific competences.

- Orange group: its mission was to propose possible activities in which the theoretical content explained is applied. The objective of this role was to develop systemic competences.

- White group: this group was divided up and integrated into the meetings of the other groups, acting as moderators whenever needed. During the presentation of results of this role, the type of need that arose in each group was indicated as well as the decisions adopted to solve the problems. The aim of the activities of this group was for students to develop interpersonal competences.

- Blue group: its mission was to assess the proposals/initiatives proposed by the other groups (red, green, orange and white), as well as indicate if they considered them to be adequate or inadequate, and why. The blue group intervened after listening to the contributions of the rest of the groups. It had 10 minutes to prepare its presentation. The aim of the activities of this group was to develop instrumental competences.

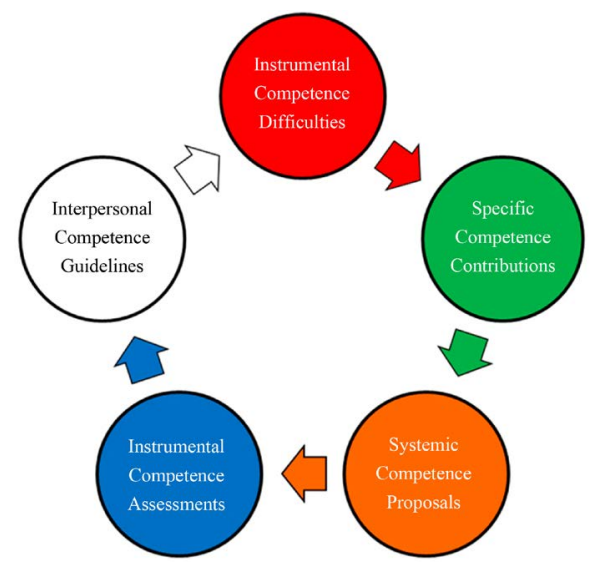

Figure 1. Change of role in each new block of content and competence development. 


\subsection{Example of the Implementation of the Methodology}

As an example the organisation and the schedule of this activity in the course of Artistic Expression is presented below. To implement this dynamic the first day of class the students were divided into 5 groups (red, green, orange, white and blue) and assigned a specific role. At the end of each theoretical explanation given by the professor, the groups met for 15 minutes to carry out the actions corresponding to each role. After performing the tasks assigned by roles, the groups presented their results orally.

Table 2 shows the organisation of classroom sessions and the development of the works done during the first semester of Artistic Expression of the Engineering Degree in Industrial Design and Product Development at the University of Zaragoza. The table shows the distribution through roles of Group 11, which comprises 39 students. The table does not include the week of class in which the visit of an expert is received and the subject of color is tackled. After each theoretical explanation by the teacher, the groups met for 15 minutes to carry out the actions corresponding to each role. After performing the tasks assigned by roles, groups reported their results verbally.

Likewise Table 3 includes a summary of comments made by the different groups in which the main contributions regarding the design theme products display panels are appreciated. The term display panel refers to media containing relevant information about a product design, concept or idea.

\section{Table 2. Development of the activity at the subject of artistic expression, course 1, group 11.}

\begin{tabular}{|c|c|c|c|}
\hline Weeks & Theory & Theory works & Roles \& groups \\
\hline Week 1 \& 2 & Product form and structure & $\begin{array}{c}\text { Products shape and structure's } \\
\text { analysis } \\
\text { Working with forms }\end{array}$ & $\begin{array}{c}\text { Red } \\
\text { Group made by } 8 \text { students }\end{array}$ \\
\hline Week 3 \& 4 & $\begin{array}{l}\text { Criterion for proportion } \\
\text { in industrial output }\end{array}$ & $\begin{array}{l}\text { Analysis of the criterion applied } \\
\text { proportion to the product }\end{array}$ & $\begin{array}{c}\text { Green } \\
\text { Group made by } 7 \text { students }\end{array}$ \\
\hline Week 5 \& 6 & $\begin{array}{l}\text { Light and volumetric } \\
\text { representation of the product }\end{array}$ & $\begin{array}{l}\text { Chiaroscuro work with different } \\
\text { types of illumination }\end{array}$ & $\begin{array}{c}\text { Orange } \\
\text { Group made by } 8 \text { students }\end{array}$ \\
\hline Week 7 \& 8 & Layout of presentation boards & Layout of products panels & $\begin{array}{c}\text { White } \\
\text { Group made by } 8 \text { students }\end{array}$ \\
\hline Week 9 \& 10 & $\begin{array}{l}\text { Color and its perception } \\
\text { in the industrial product }\end{array}$ & $\begin{array}{l}\text { Color application to } \\
\text { industrial product }\end{array}$ & $\begin{array}{c}\text { Blue } \\
\text { Group made by } 8 \text { students }\end{array}$ \\
\hline
\end{tabular}

Table 3. Example of the results of work of the different groups in the issue of product presentation boards.

\begin{tabular}{|c|c|}
\hline Roles & Topic 4. Design of presentation boards. Summary of comments \\
\hline Red & $\begin{array}{l}\text { To present as many examples of designs on products display panels that have been presented to design awards in } \\
\text { which the use of a grid is recognized. }\end{array}$ \\
\hline Green & $\begin{array}{l}\text { Utility to learn how to present product concepts. Design of backgrounds to use in display panels. } \\
\text { Perception and connotations of different fonts. }\end{array}$ \\
\hline Orange & $\begin{array}{l}\text { To design a presentation panel for a product, using the same elements in order to observe different compositional } \\
\text { choices and graphic resources proposed by each student. To share all proposals through Dropbox. }\end{array}$ \\
\hline White & $\begin{array}{l}\text { Red Group: They do not know design awards in which to observe examples of design panels. The mediator of the } \\
\text { white group proposes conduct a search for different awards and see how the products are presented. }\end{array}$ \\
\hline Blue & $\begin{array}{l}\text { Blue Group considers that the most interesting contribution has been made by the Orange group by offering the } \\
\text { possibility to share different approaches to design made among peers. }\end{array}$ \\
\hline
\end{tabular}

After the oral presentation in class, students attached the panels with the graphic summary of group work.

The activity has been assessed with a value of $10 \%$ over the final mark of the subject and a heading was designed to assess the development of the competences.

\subsection{Comparison of the Methodological Application in Different Subjects}

Once after the first semester has ended, there has been a reflection on the applied methodology in Artistic Expression and some changes to improve this dynamic and also to adapt it to the realities of the subjects of the second and third year have been proposed. The most important change was to eliminate the oral presentations at the end of each class and to replace them by a joint presentation once the theoretical part of the course has fi- 
nished. This change has been motivated by the lack of time for presentations at the end of each class and turned out to be positive, since the students have had time to synthesize the results of group work and to present it with the support of panels. At the same time this kind of presentations has served them as a review of contents. This has meant the removal of blue role throughout the course since the last day of class all students have performed it evaluating the work done by themselves and their peers.

To the white role tasks an obligation to present at least 5 proposals of possible test questions was added. This task has forced the students with this role assigned to be watchful throughout the theory class act and not only for the work of other groups. Students indicated that this work made them to review the contents carefully, which helped them to prepare for the theoretical exam.

Table 4 summarizes the changes of the methodology applied in 3 subjects taught in different degree courses.

In the next courses following this pilot experience the methodology will continue to be adapted to the needs of the subjects in which it is applied.

Table 4. Development of the activity at different courses and subjects.

\begin{tabular}{|c|c|c|c|}
\hline & $\begin{array}{l}\text { 1st course } \\
\text { Artistic expression }\end{array}$ & $\begin{array}{l}\text { 2nd course } \\
\text { Graphic design and } \\
\text { communication }\end{array}$ & $\begin{array}{l}\text { 3rd course } \\
\text { Corporate identity }\end{array}$ \\
\hline $\begin{array}{l}\text { Number of } \\
\text { registered students }\end{array}$ & 86 & 87 & 50 \\
\hline $\begin{array}{l}\text { Number of } \\
\text { surveyed students }\end{array}$ & 63 & 44 & 37 \\
\hline Size roles groups & 10 groups of about 8 students. & $\begin{array}{c}8 \text { groups between } 8 \text { and } 16 \\
\text { individuals }\end{array}$ & 8 groups of 5 individuals \\
\hline Modules & $\begin{array}{l}\text { The methodology has been applied } \\
\text { in all the theory classes }\end{array}$ & $\begin{array}{c}4 \text { classes of } 2 \text { hours }+ \text { presentation } \\
\text { of results }\end{array}$ & $\begin{array}{c}4 \text { classes of } 2 \\
\text { hours }+ \text { presentation of results }\end{array}$ \\
\hline Time spent & 15 minutes per lesson & $\begin{array}{c}4 \times 15 \text { minutes }+90 \text { minutes } \\
\text { of presentation and } \\
\text { evaluation of results }\end{array}$ & $\begin{array}{c}4 \times 15 \text { minutes }+90 \text { minutes of } \\
\text { presentation and } \\
\text { evaluation of results }\end{array}$ \\
\hline Roles rotation & $\begin{array}{l}\text { All groups have rotated through the } \\
5 \text { roles throughout the semester }\end{array}$ & $\begin{array}{l}\text { During the four classes the groups } \\
\text { were rotating between red, green, } \\
\text { orange and white roles and in the } \\
\text { presentation class all have } \\
\text { participated in the blue role }\end{array}$ & $\begin{array}{l}\text { During the four classes the } \\
\text { groups were rotating between } \\
\text { red, green, orange and white roles } \\
\text { and in the presentation class all } \\
\text { have participated in the blue role }\end{array}$ \\
\hline $\begin{array}{l}\text { Tasks assigned to } \\
\text { different roles }\end{array}$ & $\begin{array}{l}\text { Red-to detect difficulties } \\
\text { Green-to identify contributions } \\
\text { Orange-to propose activities } \\
\text { White-to mediate } \\
\text { Blue-to evaluate peers }\end{array}$ & $\begin{array}{l}\text { Red-to detect difficulties } \\
\text { Green-to identify contributions } \\
\text { Orange-to propose activities } \\
\text { White-to mediate and to } \\
\text { propose the questions for } \\
\text { the exam Blue-to evaluate } \\
\text { peers and self assessment }\end{array}$ & $\begin{array}{l}\text { Red-to detect difficulties } \\
\text { Green-to identify contributions } \\
\text { Orange-to propose activities } \\
\text { White-to mediate and to propose } \\
\text { the questions for the exam } \\
\text { Blue-to evaluate peers and self } \\
\text { assessment }\end{array}$ \\
\hline $\begin{array}{l}\text { Motivation for } \\
\text { students }\end{array}$ & $\begin{array}{l}\text {-They solve doubts. } \\
\text {-They develop skills. }\end{array}$ & $\begin{array}{c}\text {-They release } 5 \% \text { of the subject } \\
\text {-They propose questions } \\
\text { for the exam } \\
\text {-they have review class to re } \\
\text { understand issues that have } \\
\text { presented greater difficulty }\end{array}$ & $\begin{array}{l}\text {-They release } 5 \% \text { of the subject } \\
\text {-They propose questions } \\
\text { for the exam } \\
\text {-they have review class to re } \\
\text { understand issues that } \\
\text { have presented greater difficulty }\end{array}$ \\
\hline Delivery & $\begin{array}{l}\text { In the final dossier of work } \\
\text { performed. }\end{array}$ & $\begin{array}{l}\text { Through panels and } \\
\text { verbal defense in class }\end{array}$ & $\begin{array}{l}\text { Through digital media and } \\
\text { verbal defense in class }\end{array}$ \\
\hline Evaluation & Made only by the teacher & $\begin{array}{l}50 \% \text { student assessment }+50 \% \\
\text { teacher assessment }\end{array}$ & $\begin{array}{l}20 \% \text { student assessment }+80 \% \\
\text { teacher assessment }\end{array}$ \\
\hline Mark & $\begin{array}{l}\text { Up to } 15 \% \text { of the final grade for the } \\
\text { course. Final average rating } 6.8\end{array}$ & $\begin{array}{l}5 \% \text { of the course grade, } \\
\text { Final average grade } 7.6\end{array}$ & $\begin{array}{l}9.4 \text { representing } 5 \% \\
\text { of the subject }\end{array}$ \\
\hline
\end{tabular}




\subsection{Questionnaire Design and Students Sample}

A questionnaire comprised of four blocks of questions was designed with the aim to discover the following aspects: the level of affability and difficulty of each role, the extent to which the different competences are developed and the students' perception about the organisation of this activity. The questionnaire includes a total of 37 items and it was completed by a total of 64 students of the Artistic Expression subject, 44 students of Graphic Design and Communication and 37 students of Corporate Identity. This sample is representative for the population of the students enrolled in the subjects. The items have been evaluated in agreement with a Likert 7-point scale, where 1 corresponds to total disagreement and 7 with total agreement. The results obtained are described in the section below.

\section{Results and Discussion}

The results of the research are presented in four blocks. The results presented below are based on the average obtained from the evaluation of the experience of the three courses.

In the first block, the students' perception about the level of affability of each role in this activity is studied (Figure 2). Results show that the most pleasant roles were the orange and the green ones with an evaluation of 5.6 and 5.5, respectively. The blue role was the worst appraised with a score of 5.23. In general, it can be observed that all the roles exceeded 5 on the 7 scale, indicating that none of them have been unpleasant.

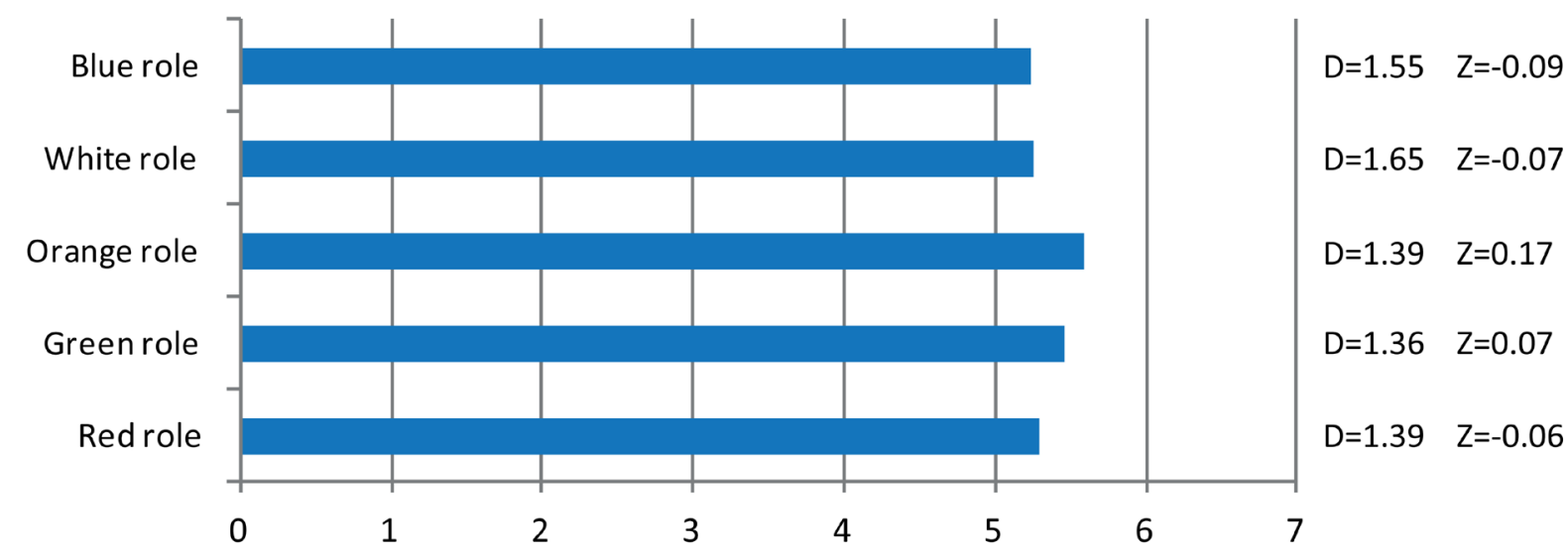

Figure 2. The students' perception of the level of affability of each role in this activity.

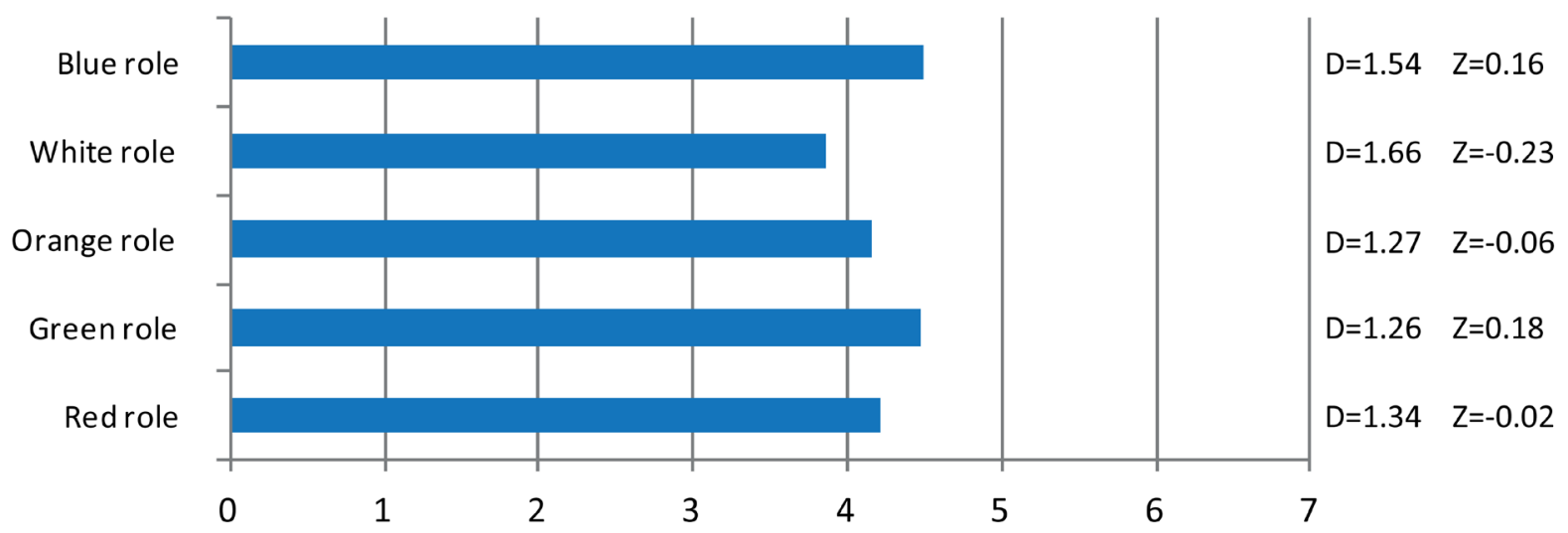

Figure 3. The students' perception of the level of difficulty of each role in this activity. D-Standard deviation. Z-Standard score.

With respect to the level of difficulty, students indicated that the blue and green roles involved the greatest difficulty with scores of 4.5 and 4.47 , respectively Figure 3. The role that turned out to be the simplest was the 
white one with a score of 3.87. Results indicate that the group and role activity has average difficulty with values of between 3.8 and 4.5 .

From the point of view of skills development (Figure 4) the students perceive that the activity helps them to learn the material, they stand that to prepare the questions for the exam helps them to study the theoretical content of the subject (6.48). They also indicate that this approach allows the development of critical thinking (6.09) and helps to compare the quality of their work from that of other group (6.08). However, the least valued aspect is referred to the fact that observing the difficulties of other groups helps to reflect on the learning process (4.98).

In general, the result obtained by the development of interpersonal, instrumental, systemic and specific competences was homogenous (between 5 and 6.5 scores), positively appraising the activity, and understanding that it helps towards developing these competences.

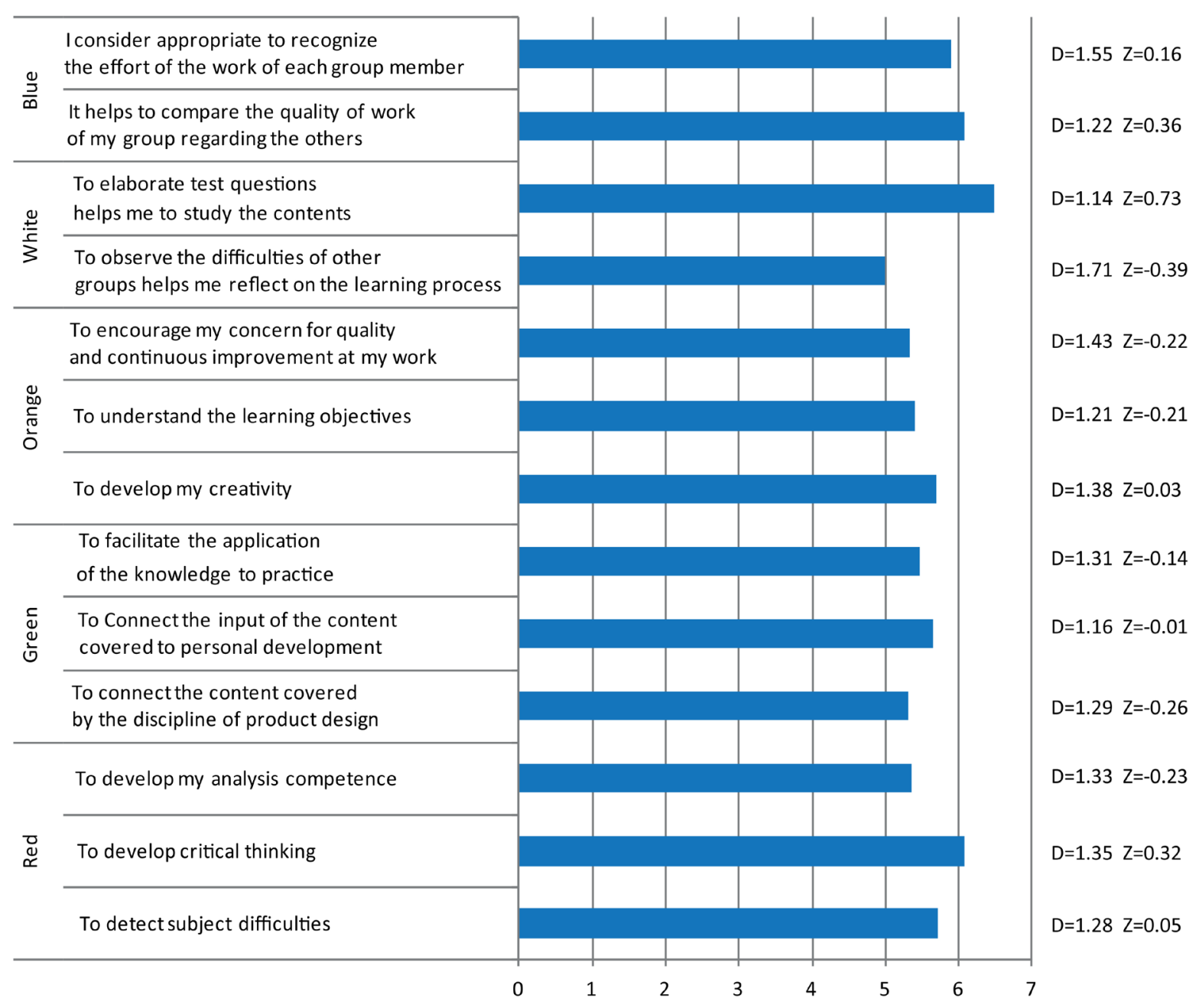

Figure 4. The students' perception of the level at which the activity helps develop competences. D-Standard deviation. ZStandard score.

The students' perception about the usefulness of this activity (Figure 5), is evaluated with 5.19, and introducing this methodology into other subjects with 4.88. With reference to the organisation of the activity, students considered that the most adequate place to carry it out was the classroom, opposed to the possibility of carrying out the experience on an online platform.

In the evaluation of experience done by the students it has been observed that with the maturity of the students the perception of the satisfaction of having participated in this activity has been higher (Figure 6). 


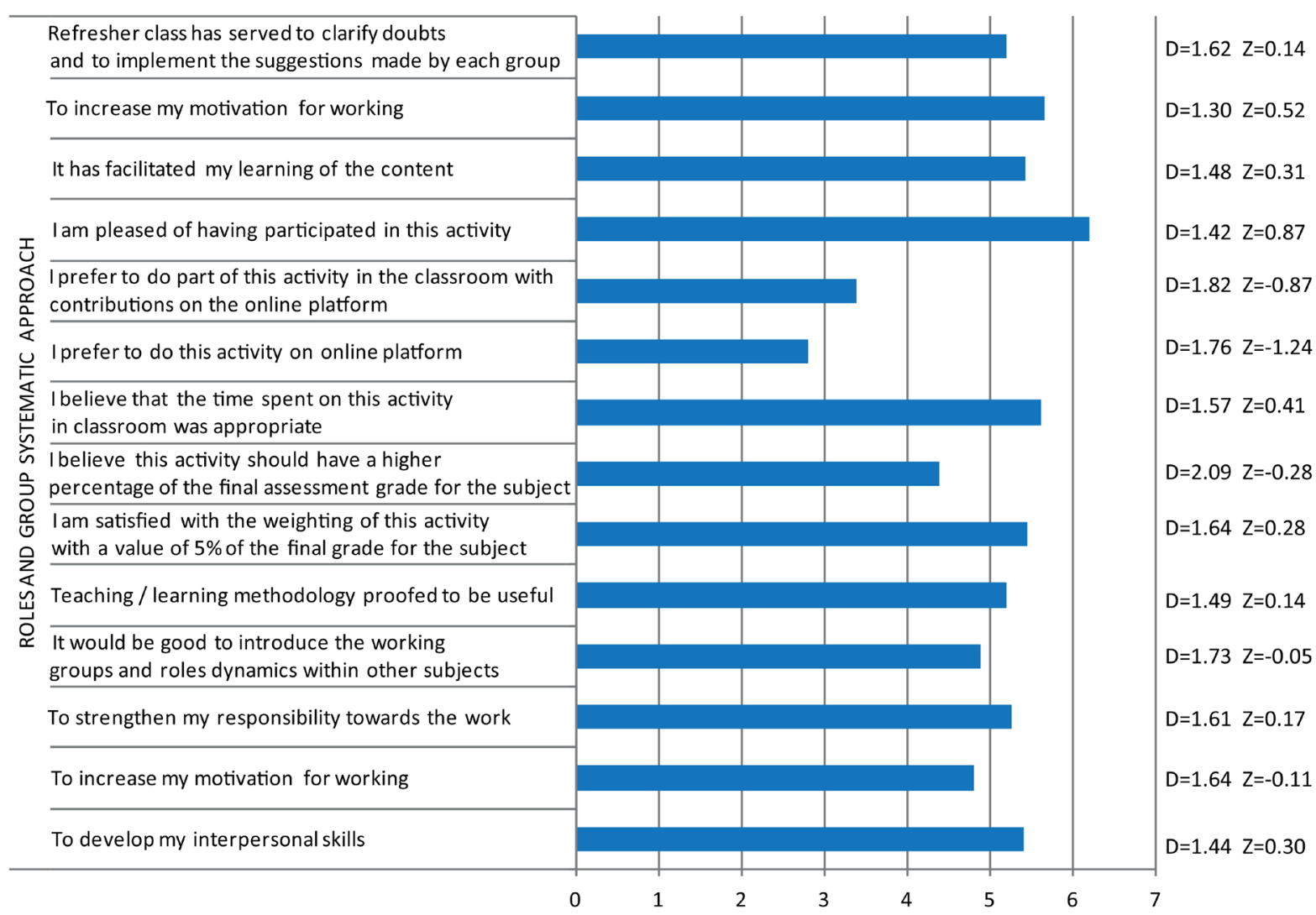

Figure 5. The students' perception of usefulness and organisation of the activity. D-Standard deviation. Z-Standard score.

I am pleased of having participated in this activity

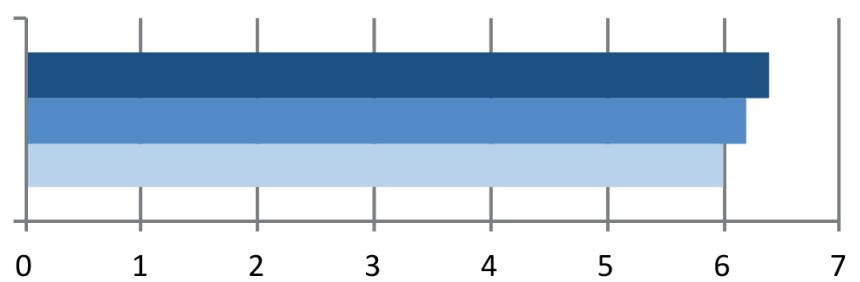

juniors

sophomores

freshmans

Figure 6. Perception of the students of the satisfaction of having participated in the activity. D-Standard deviation. Z-Standard score.

\section{Conclusion}

The methodological activity of groups and roles applied in the Engineering Degree in Industrial Design and Product Development of the University of Zaragoza (Spain), in the subject of Artistic Expression, Graphic Design and Communication and Corporate Identity, has fostered in students an active role in the acquisition of theoretical contents.

Noteworthy among the contributions of this methodology are: the application of the theoretical knowledge to real problems (green role), the development of analytical (red, blue and white roles) and creative capabilities (orange role), social skills and responsibility towards work (all of the roles).

The changes in the dynamic in classroom made in the different subjects show that it is a flexible and transferable methodology to other educational contexts. Each teacher depending on the subject, the time available and the number of participating students can adapt it according to his or her needs.

Coinciding with Martínez et al. (2007) this experience has shown that it is possible to get the teachers to gradually adopt new teaching methods to deliver their subjects and to get students to participate more actively in their learning. The adoption of this type of methodology entails an increase in teaching dedication to the teach- 
ing/learning process. However, the authors consider that it is important to continue motivating the students with new learning experiences that entail actions in which students actively develop the required competences.

The experience described is presented as a new active methodology that is in keeping with current work lines that offer the possibility of improving competences, applying a system that entails students' active participation.

Naturally, the experience carried out is in an experimental phase and its continuation will permit the improvement of this methodology, both at organisational level and from the viewpoint of tools for its evaluation.

\section{Acknowledgements}

The introduction of the Roles and Groups methodology in the subject of Corporate Identity was possible thanks to the collaboration of professor Carlos Romero Piqueras. The research has counted with the support of an Innovation Teaching Projects 2014-2015 (PIIDUZ _14_114 PROPUESTA DEAPRENDIZAJE GRUPAL POR ROLES) at the University of Zaragoza. The research was cofounded by ID ERGO, Research \& Development in Ergonomics which belongs to the Aragón Institute of Engineering Research (I3A) of the University of Zaragoza (Spain).

\section{References}

Andreu, Ma A., García, M., \& Mollar, M. (2005). La simulación y juego en la enseñanza-aprendizaje de lengua extranjera. Cuadernos Cervantes, XI, 34-38.

Atienza, J. (2008). Aprendizaje basado en problemas. Metodologías activas. Valencia: Universidad Politécnica de Valencia.

Barberá, E. (2005). Evaluación de competencias complejas: La práctica del portafolio. Educere, 9, 497-501.

Barragán, R. (2005). El portafolio, metodología de evaluación y aprendizaje de cara al nuevo espacio europeo de educación superior: Una experiencia práctica en la Universidad de Sevilla. RELATEC: Revista Latinoamericana de Tecnología Educativa, 4, 121-140.

Barros, R., \& Ramírez, C. (2009). Modelo de aprendizaje activo para desarrollar habilidades de identificación, formulación y resolución de problemas de ingeniería industrial. Revista Educación en Ingeniería, 7, 74-83.

Benegas, J., \& Villegas, M. (2006). La Enseñanza Activa de la Física: La Experiencia de la UNSL. IX Conferencia Interamericana sobre Educación en la Física, San José de Costa Rica, Costa Rica.

Bonwell, C. C., \& Eison, J. A. (1991). Active Learning: Creating Excitement in the Classroom. ASHE-ERIC Higher Education Report, Washington DC: School of Education and Human Development, George Washington University.

Bruinsma, M., \& Jansen, E. P. (2010). Is the Motivation to Become a Teacher Related to Pre-Service Teachers Intentions to Remain in the Profession? European Journal of Teacher Education, 33, 185-200.

http://dx.doi.org/10.1080/02619760903512927

Caballero, K., \& Botía, A. (2015). El profesorado univeristario como docente: hacia una identidad profesional que integre docencia e investigación. REDU: Revista de Docencia Universitaria, 13, 57-77.

Corominas, E. (2000). ¿Entramos en la era portafolio? Bordón: Revista de Orientación Pedagógica, 52, 509-521.

Fernández, A. (2006). Metodologías activas para la formación de competencias. Educatio Siglo XXI, 24, 35-56.

Francischetti, I., Mugnai, C., Massih, D. A., Mayo, M. O., Marques, A. C., Rodrigues, C. R., \& Fedel, V. L. (2014). Active Learning Methodologies: An Experience for Faculty Training at Medical Education. Creative Education, 5, 1882-1886. http://dx.doi.org/10.4236/ce.2014.521210

Franquet, T., Marín, D., Marqués, M., \& Rivas, E. (2006). El contrato de aprendizaje en la enseñanza universitaria. 4th Congreso Internacional Docencia Universitaria e Innovación, Barcelona, 5-7 July 2006, 1-15.

Garrigós, J., \& Valero, M. (2012). Hablando sobre Aprendizaje Basado en Proyectos con Júlia. REDU. Revista de Docencia Universitaria, 10, 125-151.

Hansen, J. (2006). Using Problem-Based Learning in Accounting. Journal of Education for Business, 81, 221-224. http://dx.doi.org/10.3200/JOEB.81.4.221-224

Hernández, A., González, N., \& Guerra, S. (2006). Diseño de un portafolio en la formación universitaria por competencias. Revista de Psicodidáctica, 11, 227-239.

Huber, G. L. (2008). Aprendizaje activo y metodologías educativas. Revista de Educación. Número Extraordinario, 59-81.

Johnstone, K. M., \& Biggs, S. F. (1998). Problem-Based Learning: Introduction, Analysis, and Accounting Curricula Implications. Journal of Accounting Education, 16, 407-427. http://dx.doi.org/10.1016/S0748-5751(98)00026-8

Jones, K. (1995). Simulations: A Handbook for Teachers and Trainers. London: Kogan Page Ltd. 
Juguera, L., Díaz, J. L., Pérez, M., Leal, C., Rojo, A., \& Echevarría, P. (2014). La simulación clínica como herramienta pedagógica: percepción de los alumnos de Grado en Enfermería en la UCAM (Universidad Católica San Antonio de Murcia). Enfermería Global, 13, 175-190.

Kanet, J. J., \& Barut, M. (2003). Problem-Based Learning for Production and Operations Management. Decision Sciences Journal of Innovative Education, 1, 99-118. http://dx.doi.org/10.1111/1540-5915.00007

Konopka, C. L., Adaime, M. B., \& Mosele, P. H. (2015). Active Teaching and Learning Methodologies: Some Considerations. Creative Education, 6, 1536-1545. http://dx.doi.org/10.4236/ce.2015.614154

Konrad, K. (2004). Kleingruppenprojekte. In A. A. Huber (Hrsg.), Kooperatives Lernen-Kein Problem: Effektive Methoden der Partner- und Gruppenarbeit (pp. 102-110). Stuttgart: Klett.

Lobato, C., \& Madinabeitia, A. (2011). Perfiles motivacionales del profesorado ante la formación en metodologías activas en la universidad. Formación Universitaria, 4, 37-48. http://dx.doi.org/10.4067/S0718-50062011000100006

López, F. (2005). Metodología participativa en la enseñanza universitaria. Madrid: Narcea Ediciones.

Maldonado, L. (2006). Reducción y reciclaje de residuos sólidos urbanos en centros de educación superior: Estudio de caso. Revista Ingeniería, 10, 59-68.

Manchado, E., \& López, I. (2012). Coordinación por módulos de asignaturas en el Grado de Ingeniería de Diseño Industrial y Desarrollo de Producto de la Universidad de Zaragoza. REDU. Revista de Docencia Universitaria, 10, $195-207$.

Markham, T., Larmer, J., \& Ravitz, J. (2003). Project-Based Learning Handbook: A Guide to Standards Focused ProjectBased Learning for Middle and High School Teachers. Novato, CA: Buck Institute for Education.

Martínez, B. (2008) El contrato de aprendizaje. In J. L. Piquer, \& Á. A. Andrés (Eds.), Metodologías Activas (pp. 57-64). Valencia: Universidad Politécnica de Valencia.

Martínez, B., García, J., Robledo, P., Díez, C., Álvarez, M. L., Marbán, A. M., de Caso, Fidalgo, R., Arias, O., Pacheco, D. I., \& Rodríguez, C. (2007). Valoración docente de las metodologías activas: Un aspecto clave en el proceso de Convergencia Europea. Aula Abierta, 35, 49-62.

Martínez, P. (2006). El método de estudio de caso: Estrategia metodológica de la investigación científica. Pensamiento y gestión: Revista de la división de Ciencias Administrativas de la Universidad del Norte, 20, 165-193.

Milne, M. J., \& McConnell, P. J. (2001). Problem-Based Learning: A Pedagogy for Using Case Material in Accounting Education. Accounting Education, 10, 61-82. http://dx.doi.org/10.1080/09639280122712

Moreira, F., Mesquita, D., \& Hattum-Janssen, N. V. (2011). The Importance of the Project Theme in Project-Based Learning: A Study of Student and Teacher Perceptions. 3rd International Symposium on Project Approaches in Engineering Education (PAEE2011), Lisbon, 1-2 October 2011, 65-71.

Palazón, A., Gómez, M., Gómez, J., Pérez, M., \& Gómez, J. (2011). Relación entre la aplicación de metodologías docentes activas y el aprendizaje del estudiante universitario. Bordón. Revista de Pedagogía, 63, 27-40.

Pomares, A. (2011). El modelo docente universitario y el uso de nuevas metodologías en la enseñanza, aprendizaje y evaluación. Revista de Educación, 355, 231-232.

Prendes, M. P., \& Sánchez, M. M. (2008). Portafolio electrónico: Posibilidades para los docentes. Pixel-Bit: Revista de Medios y Educación, No. 32, 21-34.

Przesmycki, H. (2000). La pedagogía del contrato. El contrato didáctico en la educación. Barcelona: GRAO.

Ramos, A. I., Herrera, J. A., \& Ramírez, M. S. (2010). Desarrollo de habilidades cognitivas con aprendizaje móvil: Un estudio de casos. Comunicar: Revista Científica Iberoamericana de Comunicación y Educación, 34, 201-209. http://dx.doi.org/10.3916/C34-2010-03-20

Rekalde, I., Martínez, B., \& Marko, J. I. (2012). Los proyectos interdisciplinares de módulo: Una experiencia innovadora en el Grado de Educación Social de la UPV/EHU. REDU. Revista de Docencia Universitaria, 10, 209-237.

Rodríguez, M. (2011). Metodologías Docentes en el EEES: De la clase magistral al portafolio. Tendencias Pedagógicas, 17, 83-103.

Romero, M. A., \& Crisol, E. (2011). El portafolio, herramienta de autoevaluación del aprendizaje de los estudiantes. Una experiencia práctica en la Universidad de Granada. Docencia e Investigación: Revista de la Escuela Universitaria de Magisterio de Toledo, 21, 25-50.

Ruiz, A. P. (2011). El modelo docente universitario y el uso de nuevas metodologías en la enseñanza, aprendizaje y evaluación. Revista de Educación, 355, 231-232.

Ruiz, D., Magallón, J., \& Muñoz, E. (2006). Herramientas de aprendizaje activo en las asignaturas de ingeniería estructural. Ingeniería y Universidad, 10, 97-115.

Saiz, C., \& Fernández, S. (2012). Pensamiento crítico y aprendizaje basado en problemas cotidianos. REDU. Revista de Docencia Universitaria, 10, 325-346. 
Serrano, A., Hernández, M., Pérez, E., \& Biel, P. (2013). Trabajo por módulos: Un modelo de aprendizaje interdisciplinar y colaborativo en el Grado en Ingeniería en Diseño Industrial y Desarrollo de Producto. REDU. Revista de Docencia Universitaria, 11, 197-220.

Sugrañes, T. F., Consarnau, D. M., Banqué, M. M., \& Nieto, E. R. (2006). El contrato de aprendizaje en la enseñanza universitaria. 4th Congreso Internacional sobre Docencia Universitaria e Innovación, Facultad de Ciencias Económicas y Empresariales de la Universidad de Barcelona, Barcelona, 5-7 de julio de 2006, 1-15.

Van Hattum, N., Fischer, A. \& Moreira, F. (2011). Presentation Skills for Engineers: Systematic Interventions in a ProjectBased Learning Course. 1st World Engineering Education Flash Week: SEFI Annual Conference, Lisboa, 27 September-4 October 2011, 645-651.

Vergara, D., \& Rubio, M. P. (2013). Una innovadora metodología para ejercitar la capacidad de visión espacial de los estudiantes de ingeniería. REDU. Revista de Docencia Universitaria, 11, 329-347.

Villarreal, O., \& Landeta, J. (2010). El estudio de casos como metodología de investigación científica en dirección y economía de la empresa. Una aplicación a la internacionalización. Investigaciones Europeas de Dirección y Economía de la Empresa, 16, 31-52. http://dx.doi.org/10.1016/S1135-2523(12)60033-1

Zabalza, M. A. (2003). Competencias docentes del profesorado universitario. Madrid: Narcea. 